\title{
Ischaemia-induced retinal neovascularisation and diabetic retinopathy in mice with conditional knockout of hypoxia-inducible factor-1 in retinal Müller cells
}

\author{
M. Lin • Y. Chen • J. Jin • Y. Hu • K. K. Zhou • M. Zhu • \\ Y.-Z. Le • J. Ge • R. S. Johnson • J.-X. Ma
}

Received: 12 November 2010 / Accepted: 19 January 2011/Published online: 1 March 2011

(C) Springer-Verlag 2011

\begin{abstract}
Aims/hypothesis Retinal Müller cells are known to produce inflammatory and angiogenic cytokines, which play important roles in diabetic retinopathy. Hypoxia-inducible factor (HIF)-1 has been shown to play a crucial role in retinal inflammation and neovascularisation. We sought to determine the role of Müller cell-derived HIF-1 in oxygeninduced retinopathy (OIR) and diabetic retinopathy using conditional Hif-1 $\alpha$ (also known as Hifla) knockout (KO) mice.

Methods Conditional Hif-1 $\alpha$ KO mice were generated by crossing mice expressing cyclisation recombinase (cre, also
\end{abstract}

Electronic supplementary material The online version of this article (doi:10.1007/s00125-011-2081-0) contains supplementary material, which is available to authorised users.

M. Lin · Y. Chen · J. Jin · Y. Hu • K. K. Zhou · J.-X. Ma

Department of Physiology,

The University of Oklahoma Health Sciences Center,

Oklahoma City, OK, USA

M. Zhu • Y.-Z. Le • J.-X. Ma

Department of Medicine,

The University of Oklahoma Health Sciences Center,

Oklahoma City, OK, USA

Y.-Z. Le

Department of Cell Biology,

The University of Oklahoma Health Sciences Center,

Oklahoma City, OK, USA

M. Zhu $\cdot$ Y.-Z. Le $\cdot$ J.-X. Ma

Harold Hamm Oklahoma Diabetes Center,

The University of Oklahoma Health Sciences Center,

Oklahoma City, OK, USA

M. Lin $\cdot$ J. Ge

State Key Laboratory of Ophthalmology,

Guangzhou, People's Republic of China known as P1_gp003) in Müller cells with floxed Hif-1 $\alpha$ mice and used for OIR and streptozotocin-induced diabetes to induce retinal neovascularisation and inflammation, respectively. Abundance of HIF- $1 \alpha$ and pro-angiogenic and pro-inflammatory factors was measured by immunoblotting and immunohistochemistry. Retinal neovascularisation was visualised by angiography and quantified by counting pre-retinal nuclei. Retinal inflammation was evaluated by leucostasis and vascular leakage.

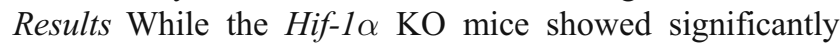
decreased HIF- $1 \alpha$ levels in the retina, they exhibited no apparent histological or visual functional abnormalities

\author{
M. Lin J. Ge \\ Zhongshan Ophthalmic Center, Sun Yat-sen University, \\ Guangzhou, People's Republic of China
}

\section{R. S. Johnson}

Department of Biology, University of California,

San Diego, CA, USA

J.-X. Ma $(\bowtie)$

941 Stanton L. Young Blvd, BSEB 328B,

Oklahoma City, OK 73104, USA

e-mail: jian-xing-ma@ouhsc.edu

J. Ge $(\bowtie)$

54 S. Xianlie Rd,

Guangzhou, People's Republic of China 510060

e-mail: gejian@mail.sysu.edu.cn 
under normal conditions. Compared with wild-type counterparts, Hif- $1 \alpha \mathrm{KO}$ mice with OIR demonstrated attenuated overproduction of vascular endothelial growth factor (VEGF) and intercellular adhesion molecule (ICAM)-1, reduced vascular leakage and alleviated neovascularisation in the retina. Under diabetes conditions, disruption of Hif- $1 \alpha$ in Müller cells attenuated the increases of retinal vascular leakage and adherent leucocytes, as well as the overproduction of VEGF and ICAM-1.

Conclusions/interpretation Müller cell-derived HIF-1 $\alpha$ is a key mediator of retinal neovascularisation, vascular leakage and inflammation, the major pathological changes in diabetic retinopathy. Müller cell-derived HIF- $1 \alpha$ is therefore a promising therapeutic target for diabetic retinopathy.

Keywords Angiogenesis - Diabetic retinopathy · Hypoxia . Ischaemia $\cdot$ Müller cells $\cdot$ Retina

$\begin{array}{ll}\text { Abbreviations } \\ \text { ERG } & \text { Electroretinogram } \\ \text { GS } & \text { Glutamine synthetase } \\ \text { HIF } & \text { Hypoxia-inducible factor } \\ \text { ICAM } & \text { Intercellular adhesion molecule } \\ \text { KO } & \text { Knockout } \\ \text { OIR } & \text { Oxygen-induced retinopathy } \\ \text { P } & \text { Postnatal day } \\ \text { VEGF } & \text { Vascular endothelial growth factor } \\ \text { VHL } & \text { von Hippel-Lindau tumour-suppressor protein }\end{array}$

\section{Introduction}

Angiogenesis is an important physiological process in development and wound healing [1]. It is well known that angiogenesis is controlled by a delicate balance of proangiogenic and anti-angiogenic factors in tissues [2]. Dysregulation of this balance has been shown to result in pathological angiogenesis such as diabetic retinopathy and cancer [1]. Extensive studies have shown that oxygensensing systems play important roles in maintaining the balance of angiogenesis regulation. Hypoxia-inducible factor (HIF)-1 is a key oxygen sensor and mediator of angiogenesis [3-5].

HIF-1 is a heterodimer consisting of an $\mathrm{O}_{2}$-regulated HIF- $1 \alpha$ subunit and a constitutive HIF-1 $\beta$ subunit [6]. Under normoxia, HIF- $1 \alpha$ is constantly synthesised and degraded. The degradation of HIF- $1 \alpha$ is triggered by binding of the von Hippel-Lindau tumour-suppressor protein (VHL). As VHL interacts with the protein Elongin C, recruits an E3 ubiquitin-protein ligase complex and ubiquitinates HIF- $1 \alpha$, HIF- $1 \alpha$ is degraded by the $26 S$ proteasome $[7,8]$. VHL binding is dependent on hydroxylation of Pro402 or Pro564, or both, by a dioxygenase called the prolyl hydroxylase domain protein 2 [9, 10]. However, activity of this dioxygenase decreases under hypoxic conditions [11-13]. Therefore, HIF- $1 \alpha$ is accumulated, dimerises with HIF-1 $\beta$, is transported into the nucleus and binds to the hypoxiaresponsive elements in the promoters of target genes, such as those encoding vascular endothelial growth factor (VEGF) and erythropoietin, which are key pro-angiogenic factors and pathogenic factors in diabetic retinopathy [14].

Retinal Müller cells are the principal supporting cells in the neural retina and participate in retinal angiogenesis, neural protection and other physiological functions $[15,16]$. Recent studies have indicated that HIF-1 $\alpha$ is produced in all of the retinal layers [17]. Under hypoxic conditions, HIF-1 $\alpha$, VEGF and erythropoietin levels increase rapidly in the inner retina, particularly in a central region of the inner nuclear layer, where Müller cell nuclei are located. The finding that disruption of Müller cell-derived VEGF resulted in significant inhibition of ischaemia-induced retinal neovascularisation and vascular leakage strongly suggests that retinal Müller cell-derived VEGF is a major contributor to retinal neovascularisation [18]. However, VEGF production is regulated by multiple transcription factors in addition to HIF-1. To determine the role of HIF-1 produced in Müller cell in ischaemia-induced overproduction of VEGF and retinal neovascularisation, we generated conditional Hif- $1 \alpha$ (also known as Hifla) knockout (KO) mice using the cre (also known as P1_gp003)/lox system. This report describes our initial characterisation of Hif-1 $\alpha \mathrm{KO}$ mice in hypoxia and diabetes.

\section{Methods}

Generation of conditional Hif- $1 \alpha$ KO mice and animal treatment All animal experiments were performed following the guidelines of the Association for Research in Vision and Ophthalmology (ARVO) 'Statement on the Use of Animals in Ophthalmic and Vision Research' and approved by the Institutional Animal Care and Use Committee (Protocol 08-175 H1). Conditional Hif-1 $\alpha$ KO mice were generated by mating Müller cell-expressing cre mice with floxed Hif- $1 \alpha$ mice (electronic supplementary material [ESM] Fig. 1a) [15, 19]. Genotyping was performed using primers with sequences 5'-GCAGTTAAGAGCAC TAGTTG-3' and 5'-GGAGCTATCTCCTAGACC-3' to detect a $220 \mathrm{bp}$ product from the wild-type allele and a 280 bp product for the floxed Hif- $1 \alpha$ allele (ESM Fig. 1b) [17]. PCR for cre was performed using primers 5'AGGTGTAGAGAAGGCACTTAGC-3' and 5'CTAATCGCCATCTTCCAGCAGG-3' to detect a 411 bp product (ESM Fig. 1b) [15]. Hif-1 $\alpha$ disruption in the Hif$1 \alpha \mathrm{KO}$ mice was induced by feeding doxycycline at a dose 
of $2 \mathrm{mg} / \mathrm{ml}$ in $5 \%$ (wt/vol.) sucrose solution from embryonic day 15 to postnatal day 1 (P1).

Oxygen-induced retinopathy (OIR) was generated by placing mice in $75 \%$ (vol./vol.) oxygen from P7 to P12 and then returning them to room air. Diabetes was induced in 8to 10-week-old male mice (19-24 g) by five daily intraperitoneal injections of streptozotocin (Sigma, St

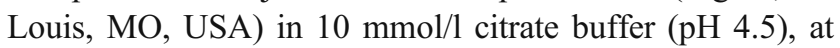
a dose of $55 \mathrm{mg} / \mathrm{kg}$ body weight after fasting for $8 \mathrm{~h}$. Agematched controls received citrate buffer. Fasting blood glucose was measured 1 week after the last injection of streptozotocin and every 2 weeks thereafter. Only mice maintaining glucose levels $>16.65 \mathrm{mmol} / 1$ for 2 months were used for this study. No insulin was given to the diabetic mice.

Primary Müller cell culture Primary Müller cells were cultured as described previously $[15,20]$. The retinas were isolated, minced into $\sim 1 \mathrm{~mm}^{2}$ fragments and cultured in DMEM with $10 \%$ (vol./vol.) FBS and 1\% (wt/vol.) penicillin/streptomycin. After the cultures had been maintained for 3 days in $5 \%$ (vol./vol.) $\mathrm{CO}_{2}$ at $37^{\circ} \mathrm{C}$, the retinal aggregates were removed. Serum-free DMEM medium was applied before further analysis. Cultured cells of fourth to sixth passages were used.

Electroretinogram recording Electroretinogram (ERG) measurement was performed as described previously [21]. Dark adaptation time was $12 \mathrm{~h}$, light adaption time $15 \mathrm{~min}$. The flash intensities were 1,000 and $2,000 \mathrm{~cd} \mathrm{~s}^{-1} \mathrm{~m}^{2}$. The duration of light stimulation was $10 \mathrm{~ms}$. The band pass was set at 0.3 to $500 \mathrm{~Hz}$. For quantitative analysis, the B-wave amplitude was measured between the peaks of A- and Bwaves. The ERG waveforms of both eyes in the same animal were simultaneously recorded.

Retinal morphology examination Eyes were fixed for $48 \mathrm{~h}$, embedded in paraffin and sectioned $(5 \mu \mathrm{m}$ thickness). Sections were stained with haematoxylin and eosin, and examined under a light microscope. Morphometric analysis of retinal sections was performed as described previously [22].

Western blot analysis Western blot analysis was performed as described previously [23, 24]. The protein concentration was determined using the Bradford assay. Mouse anti- $\beta$-actin antibody (1:4,000 dilution; Abcam, Cambridge, MA, USA), goat anti-albumin antibody (1:3,000 dilution; Bethyl Laboratories, Montgomery, TX, USA), rabbit anti-HIF- $1 \alpha$ antibody (NB100-479, 1:2,000 dilution; Novus Biologicals, Littleton, CO, USA), rabbit anti-TNF- $\alpha$ antibody (1:2,500 dilution; Abcam), mouse anti-VEGF antibody (C15, 1:500 dilution; Santa Cruz
Biotechnologies, Santa Cruz, CA, USA) and mouse antiintercellular adhesion molecule (ICAM)-1 antibody (1:500 dilution; Santa Cruz) were used to detect each protein and blotted with a horseradish peroxidase-conjugated secondary antibody. The signal was developed with Super Signal West Dura extended duration substrate (Thermo Scientific, Rockford, IL, USA) and images captured by an image station (Chemi Genius; SynGene, Frederick, MD, USA). Blots were then stripped and re-blotted with an antibody specific for $\beta$-actin.

Immunohistochemistry Eyecups were treated for $15 \mathrm{~min}$ in $4 \%$ (wt/vol.) paraformaldehyde, then with $10 \%(\mathrm{wt} / \mathrm{vol}$.), $20 \%$ (wt $/ \mathrm{vol}$.) and 30\% (wt/vol.) sucrose, and embedded in optimal cutting temperature compound (Tissue-Tek; Sakura Finetek, Torrance, CA, USA). Sections were cut and blocked with $10 \%$ (vol./vol.) normal goat serum, $3 \%$ (wt/vol.) BSA and $0.25 \%$ (vol./vol.) Triton X-100. Slides were incubated with the anti-HIF-1 $\alpha$ antibody (NB 100 479, 1:100 dilution; Novus Biologicals) or an anti-VEGF antibody (C15; $1: 50$ dilution; Santa Cruz), and doublestained with a rabbit anti-glutamine synthetase (GS) antibody (1:1,000 dilution; Abcam). The slides were then incubated for $1 \mathrm{~h}$ with Cy3- and FITC-labelled secondary antibodies (Jackson ImmunoResearch Europe, Newmarket, UK), and mounted with a mounting medium for fluorescence with DAPI (Vector Laboratories, Burlingame, CA, USA). For in vitro assay, the cells were fixed with $4 \%$ paraformaldehyde for $10 \mathrm{~min}$ and incubated with $0.1 \%$ (vol./vol.) Triton X-100. The fixed cells were stained with an anti-GS $(1: 10,000$ dilution) or an anti-HIF-1 $\alpha$ antibody (NB 100-479, 1:1,000 dilution).

ELISA for VEGF A commercial mouse VEGF ELISA kit (R\&D Systems, Minneapolis, MN, USA) was used according to the manufacturer's instruction to measure VEGF levels, with results normalised to total protein concentrations.

Retinal angiography Retinal angiography was performed as described previously [25]. For analysis of the retinal vessel density in mice under normal conditions, angiographic images were used to count the mean microvessel intersections, as described $[15,26]$.

Quantification of retinal neovascularisation Pre-retinal neovascularisation was quantified as described previously [27]. Retinal sections with haematoxylin and eosin staining were examined under a light microscope. All nuclei found on the vitreal side of the inner limiting membrane were considered vascular cells, as in normal conditions few nuclei can be found in the vitreous on a cross-section. Eight 
discontinuous sections per eye were used to quantify preretinal vascular cells.

Leucostasis assay The assay was performed as described previously [21]. Briefly, mice were perfused through the left ventricle to remove circulating leucocytes in blood vessels. The adherent leucocytes in the vasculature were stained by perfusion with FITC-conjugated concanavalin-A (40 $\mu \mathrm{g} / \mathrm{ml}$; Vector Laboratories) and counted.

Statistical analysis The quantitative data were analysed and compared with those from wild-type mice using unpaired Student's $t$ test (two-tailed test). Statistical significance was set at $p<0.05$.

\section{Results}

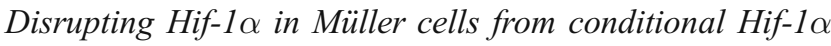
$K O$ mice To determine the efficiency of Hif- $1 \alpha$ disruption, primary Müller cells were isolated from the retinas of newborn Hif- $1 \alpha \mathrm{KO}$ mice. The identity and purity of the primary cells were confirmed by immunocytochemistry using an antibody against GS, a Müller cell marker, which showed more than $95 \%$ of the isolated cells to be Müller cells (Fig. 1a, b). Immunostaining showed that Müller cells from Hif- $1 \alpha \mathrm{KO}$ mice had an apparent decrease of HIF-1 $\alpha$ signals compared with those from wild-type mice (cre-Hif- $1 \alpha$ floxed) under normoxic and hypoxic conditions (Fig. 1d-o).

Western blot analysis demonstrated that HIF- $1 \alpha$ levels were decreased significantly in primary Müller cells derived from Hif-1 $\alpha \mathrm{KO}$ mice under normoxia compared with their wild-type counterparts (Fig. 1p). Exposure of wild-type cells to hypoxia upregulated HIF- $1 \alpha$ levels significantly $(p<0.01$; Fig. 1p). In contrast, hypoxia-induced increase of HIF- $1 \alpha$ production was partially attenuated in cells from Hif- $1 \alpha \mathrm{KO}$ mice.

Similarly, abundance of VEGF, a target of HIF-1, was significantly induced by hypoxia in wild-type Müller cells, but not in those from Hif-1 $\alpha \mathrm{KO}$ mice (Fig. 1q).
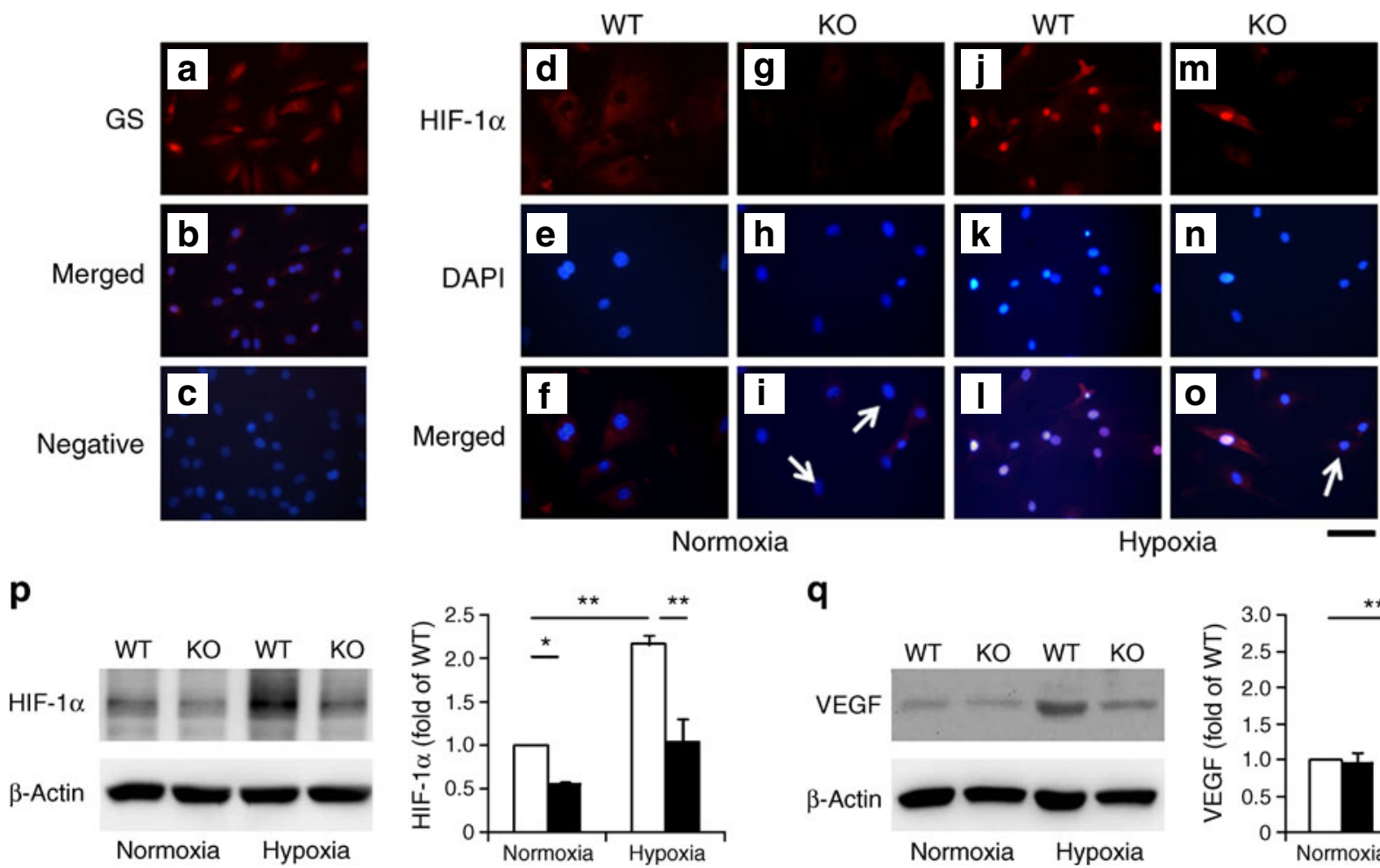

Hypoxia

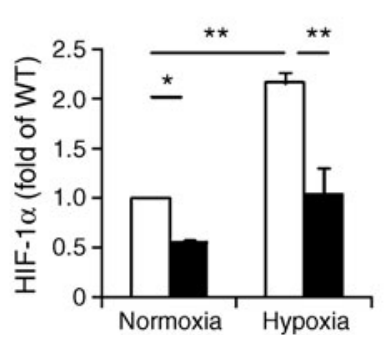

Fig. 1 Abundance of HIF- $1 \alpha$ and VEGF in primary Müller cells isolated from conditional Hif- $1 \alpha \mathrm{KO}$ mice. a Immunostaining of GS (red) in primary Müller cells and (b) GS staining merged with DAPI (blue). c Negative control for GS, in which the primary antibody was omitted. $\mathbf{d}, \mathbf{g}, \mathbf{j}, \mathbf{m}$ Immunostaining of HIF-1 $\alpha$ (red signal) in primary Müller cells from wild-type (WT) and Hif-1 $\alpha \mathrm{KO}$ mice under normoxic or hypoxic conditions. $\mathbf{e}, \mathbf{h}, \mathbf{k}, \mathbf{n}$ Nuclear staining of cells as above $(\mathbf{d}, \mathbf{g}, \mathbf{j}, \mathbf{m})$ with DAPI (blue) and $(\mathbf{f}, \mathbf{i}, \mathbf{l}, \mathbf{o})$ merged images. Arrows indicate Müller cells with disrupted HIF-1 $\alpha$. Scale bar $50 \mu \mathrm{m}$. p Western blot analysis of HIF-1 $\alpha$ in primary Müller cells,
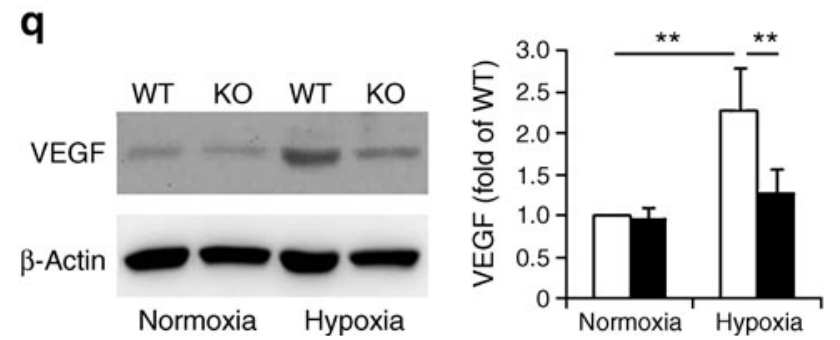

with HIF- $1 \alpha$ levels quantified by densitometry and normalised by $\beta$ actin levels (not mentioned in following quantification). HIF- $1 \alpha$ was significantly decreased in the Müller cells from Hif- $1 \alpha \mathrm{KO}$ mice (black bars) under normoxic conditions to $57 \%$ of that in the WT (white bars) cells. Under hypoxia, HIF- $1 \alpha$ levels in Hif- $1 \alpha \mathrm{KO}$ cells were $49 \%$ of those in the wild-type cells. q Western blot analysis, with quantification, of VEGF. VEGF levels were significantly decreased in primary Müller cells from Hif-1 $\alpha \mathrm{KO}$ mice under hypoxic conditions. Values $(\mathbf{p}, \mathbf{q})$ are mean \pm SEM; $n=3 ;{ }^{*} p<0.05$ and $* * p<0.01$ 
Retinal development in the Hif-1 $\alpha$ KO mice To determine whether disrupting the Hif-1 $\alpha$ gene in Müller cells affects retinal development, we examined retinal morphology, vasculature and visual function in Hif- $1 \alpha \mathrm{KO}$ mice. Under normal conditions, no apparent retinal morphological change was observed in 3-month-old Hif- $1 \alpha \mathrm{KO}$ mice compared with wild-type controls (Fig. 2a-c). Fluorescein angiography also demonstrated similar retinal vascular densities and patterns in both mouse groups (Fig. 2d-f) at P17. Scotopic and photopic ERG recordings showed no significant differences in A-wave and B-wave amplitudes between wild-type and $\mathrm{KO}$ mice at the age of 3 months (Fig. 2g, h), suggesting that disruption of Hif-1 $\alpha$ in Müller cells did not affect development of the retina.

Decreased retinal levels of HIF-1 $\alpha$ in the retina of Hif-1 $\alpha$ $K O$ mice Retinal HIF- $1 \alpha$ levels were compared in wildtype and Hif- $1 \alpha \mathrm{KO}$ mice under normal conditions and in mice with OIR, an ischaemia-induced model of retinal neovascularisation. As shown by immunohistochemistry using an anti-HIF- $1 \alpha$ antibody, under normal conditions only basal levels of HIF- $1 \alpha$ staining in the retinas were detected in Hif- $1 \alpha \mathrm{KO}$ mice and wild-type controls. However, OIR substantially increased the intensity of HIF- $1 \alpha$ signals in the inner retina of wild-type mice. In contrast, Hif-1 $\alpha \mathrm{KO}$ mice showed suppressed upregulation of HIF- $1 \alpha$ signals induced by OIR compared with their wild-type counterparts (Fig. 3a-1; ESM Fig. 2). Western blotting also showed a substantial increase of retinal HIF$1 \alpha$ by OIR in wild-type mice, while OIR-induced accumulation of HIF- $1 \alpha$ was reduced in Hif- $1 \alpha \mathrm{KO}$ mice (Fig. 3m). Semi-quantification of the blots by densitometry showed that in the OIR model, total HIF- $1 \alpha$ levels were approximately twofold lower in retinas of $H i f-1 \alpha \mathrm{KO}$ mice than in wild-type retinas (Fig. 3n).

Hif-1 $\alpha$ KO prevented ischaemia-induced overabundance of $V E G F$ To evaluate how disruption of Hif- $1 \alpha$ in Müller cells
Fig. 2 Retinal morphology and function in Hif- $1 \alpha \mathrm{KO}$ mice. a Representative retinal sections of 12-week-old wild-type (WT) and (b) Hif- $1 \alpha \mathrm{KO}$ mice stained with haematoxylin and eosin. ONL, outer nuclear layer; INL, inner nuclear layer; GCL, ganglion cell layer. Scale bar $50 \mu \mathrm{m}$. c Quantification of thickness of retina as labelled in WT (white bars) and Hif-1 $\alpha$ KO (black bars) mice; $n=5$. d Retinal fluorescein angiography of WT and (e) Hif- $1 \alpha \mathrm{KO}$ mice at age P17. Scale bar $100 \mu \mathrm{m}$. f Quantification of retinal vessel density; $n=8$. g Scotopic and (h) photopic ERGs were recorded at age 12 weeks and amplitudes of A- and B-waves were measured; $n=9$. Values $(\mathbf{c}, \mathbf{f}, \mathbf{g}, \mathbf{h})$ are mean $\pm \mathrm{SEM}$, $p>0.05$
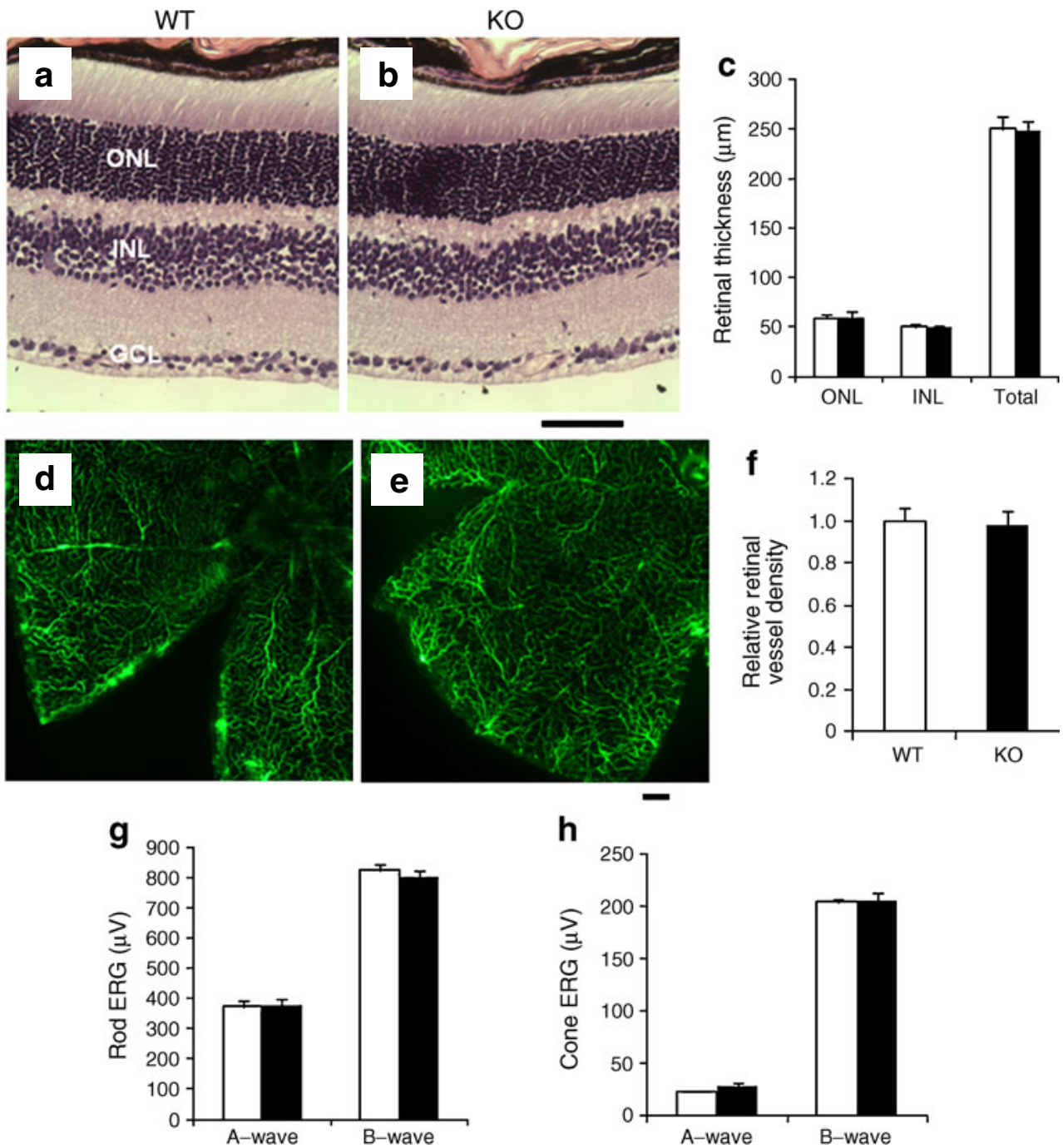
Fig. 3 Decreased HIF-1 $\alpha$ protein levels in retinas of Hif-1 $\alpha$ $\mathrm{KO}$ mice. a-f Immunostaining in wild-type (WT) and Hif-1 $\alpha$ $\mathrm{KO}$ mice under normal conditions or $(\mathbf{g}-\mathbf{l})$ with OIR at P17. a, d, g, j Nuclear staining by DAPI (pseudocolour red); $(\mathbf{b}, \mathbf{e}, \mathbf{h}, \mathbf{k}) \mathrm{HIF}-1 \alpha$ staining (green); (c, f, i, l) merged images. Scale bar $50 \mu \mathrm{m}$. ONL, outer nuclear layer; INL, inner nuclear layer; GCL, ganglion cell layer. $\mathbf{m}$ Western blot analysis of HIF- $1 \alpha$ at P17. The same amount $(20 \mu \mathrm{g})$ of retinal proteins from each mouse was blotted with an antibody specific for HIF- $1 \alpha$ and an antibody specific for $\beta$-actin. $\mathbf{n}$ The abundance of HIF- $1 \alpha$ was significantly decreased in retina of Hif-1 $\alpha \mathrm{KO}$ mice (black bars) compared with that in the WT mice (white bars) under normal or hypoxic conditions. Values are mean \pm SEM; $n=6 ;{ }^{*} p<0.05$ and $* * p<0.01$
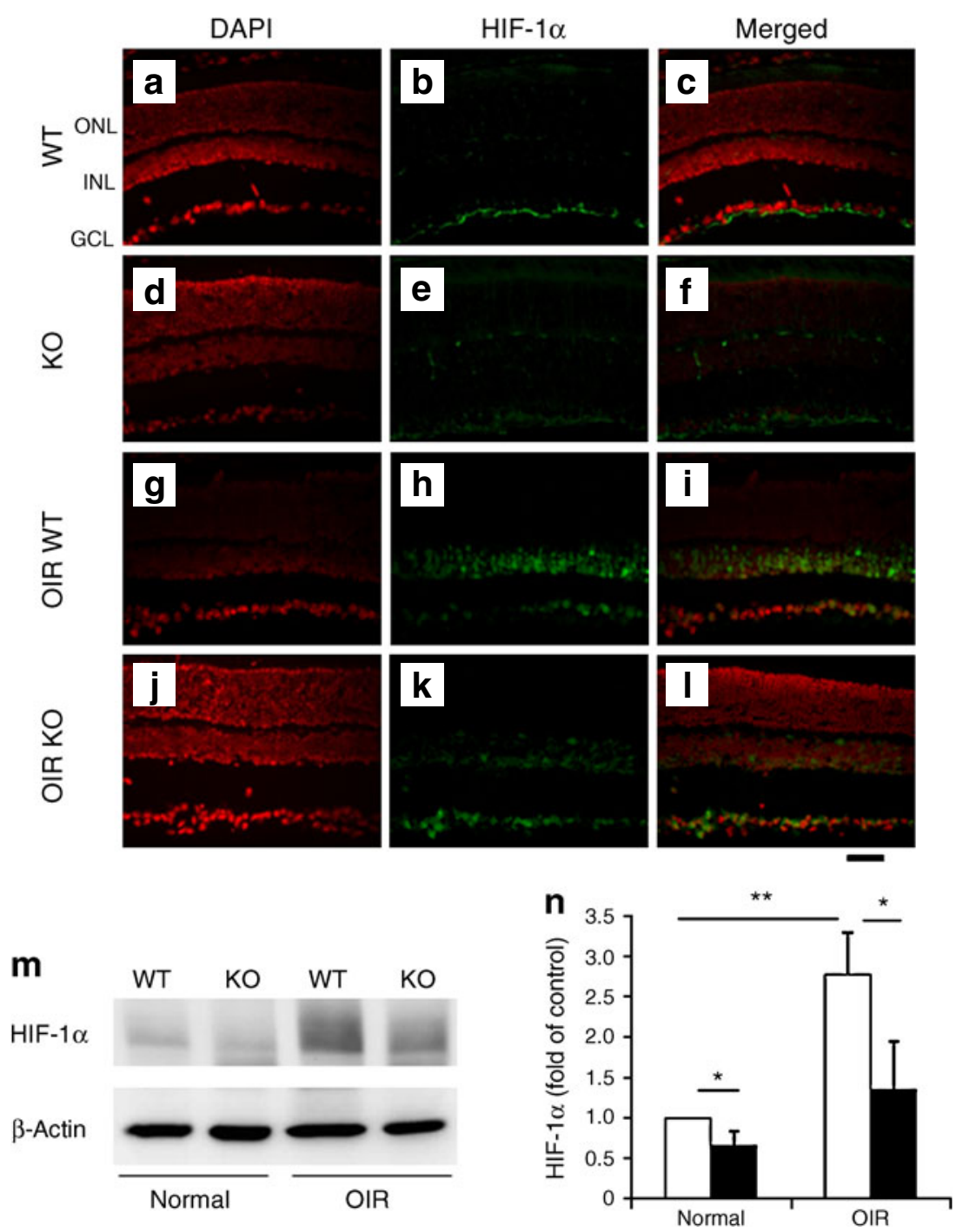

affected the overabundance of VEGF, we determined levels of VEGF in the retina. Under normal conditions, no apparent difference was detected between wild-type and Hif- $1 \alpha \mathrm{KO}$ mice in VEGF signals in the retinal sections. Consistent with previous studies [15], OIR induced a dramatic overabundance of VEGF, primarily in the inner retina of wild-type mice (Fig. $4 \mathrm{~g}$ ). Under the same OIR condition, overabundance of VEGF was attenuated in the retina of Hif- $1 \alpha \mathrm{KO}$ mice (Fig. 4a-1; ESM Fig. 3). Western blot analysis showed that VEGF production in the retina of OIR-treated wild-type mice was induced almost fivefold more abundantly than in normal wild-type mice, while Hif- $1 \alpha \mathrm{KO}$ mice with OIR only showed threefold increases in retinal VEGF levels compared with $\mathrm{KO}$ mice under normal conditions (Fig. 4m, n). ELISA results also showed that the VEGF overproduction induced by OIR was significantly attenuated in the retinas of $\mathrm{Hif}-1 \alpha \mathrm{KO}$ mice compared with wild-type controls under the same
OIR conditions (Fig. 4o), suggesting that HIF-1 $\alpha$ in Müller cells is a major mediator of ischaemia-induced VEGF overproduction in the retina.

Retinal inflammation and vascular leakage were attenuated in OIR-treated Hif-1 $\alpha \mathrm{KO}$ mice ICAM-1 is a major inflammatory factor and plays important roles in diabetic retinopathy [21]. Western blot analysis showed that retinal levels of ICAM-1 were similar in wild-type and Hif-1 $\alpha \mathrm{KO}$ mice under normoxia (Fig. 5a, b). OIR significantly induced ICAM-1 production in the retina of wild-type mice, but this effect was abolished in Hif-1 $\alpha \mathrm{KO}$ mice (Fig. 5a, b).

To evaluate vascular leakage, serum albumin was measured in the retina after removal of albumin in the vasculature by thorough perfusion. Western blot analysis showed that retinal albumin was significantly increased by OIR in wild-type mice (Fig. 5b), a finding consistent with 
Fig. 4 Attenuated VEGF overproduction in retinas of $H i f-1 \alpha$ KO mice. a, d Immunohistochemical staining of VEGF (red) in wild-type (WT) and the Hif- $1 \alpha \mathrm{KO}$ mice under normoxia or $(\mathbf{g}, \mathbf{j})$ with OIR at age P17. b, e, h, $\mathbf{k}$ GS staining (green) and $(\mathbf{c}, \mathbf{f}, \mathbf{i}, \mathbf{l})$ merged VEGF and GS staining with DAPI staining (blue) in mice as above (a, d, g, j). Scale bar $50 \mu \mathrm{m}$. GCL, ganglion cell layer; INL, inner nuclear layer; ONL, outer nuclear layer. m Retinal VEGF was determined by western blot analysis using $20 \mu \mathrm{g}$ retinal protein from each mouse. $\mathbf{n}$ Densitometry of the western blot showed that VEGF was significantly lower in the retina of Hif- $1 \alpha \mathrm{KO}$ mice (black bars) with OIR than in WT mice VEGF levels were also measured with ELISA, showing that the overproduction of VEGF was attenuated in Hif- $1 \alpha \mathrm{KO}$ mice under hypoxic conditions. Values $(\mathbf{n}, \mathbf{o})$ are mean $\pm \mathrm{SEM} ; n=6$; ${ }^{*} p<0.05$ and $* * p<0.01$ (white bars) with OIR. o Retinal
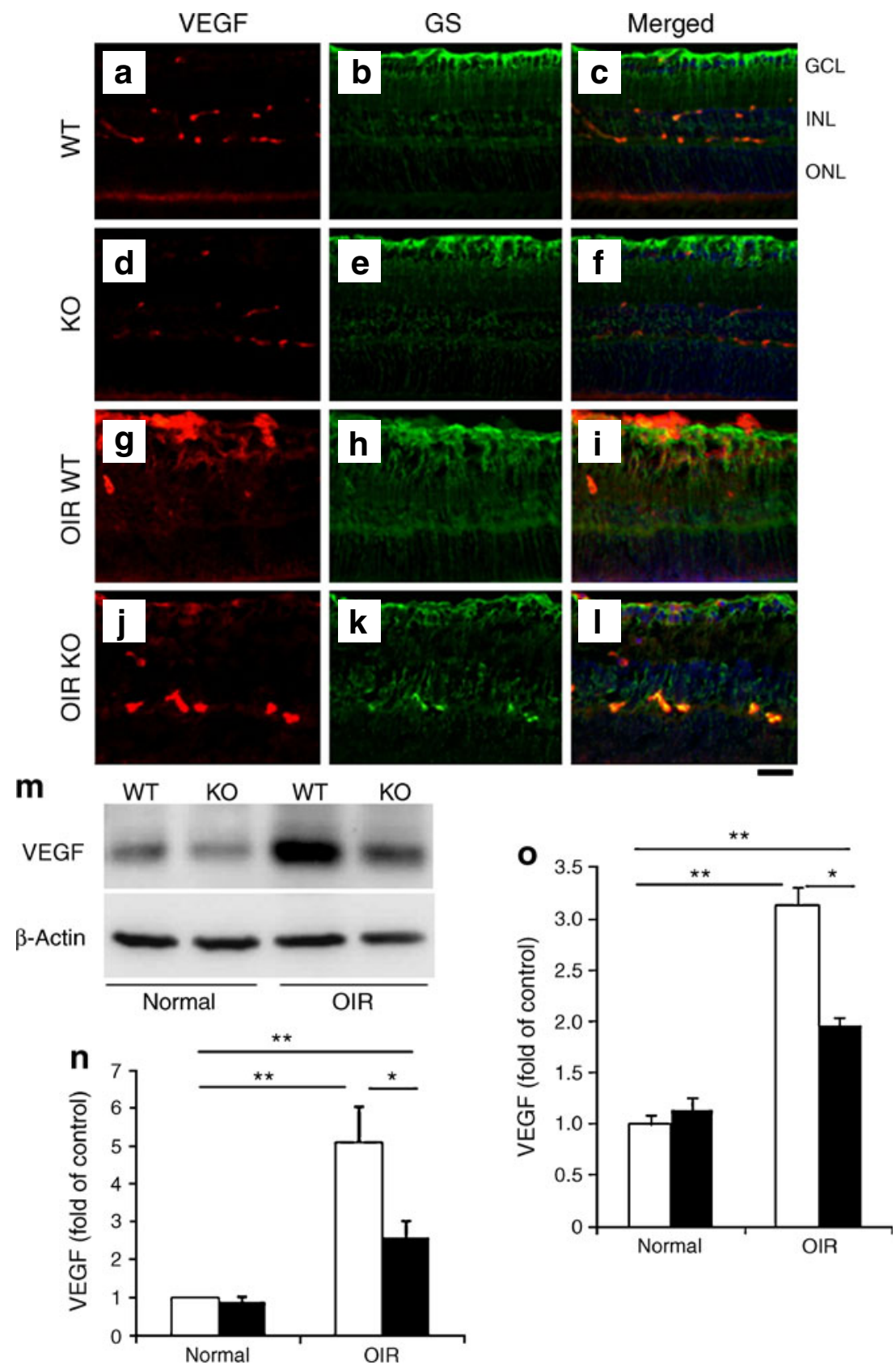

previous reports that OIR increases vascular permeability in the retina [15]. However, the elevation of retinal albumin was attenuated in Hif- $1 \alpha \mathrm{KO}$ mice, suggesting an essential role of Müller cell-derived HIF-1 $\alpha$ in ischaemia-induced vascular leakage (Fig. 5b).

Attenuation of ischaemia-induced retinal neovascularisation in Hif-1 $\alpha \mathrm{KO}$ mice To evaluate the contribution of Müller cell-derived HIF-1 $\alpha$ to ischaemia-induced retinal neovascularisation, angiography with high molecular mass fluorescein-dextran was performed in OIR-treated mice at $\mathrm{P} 17$. Hif- $1 \alpha \mathrm{KO}$ mice showed an apparent reduction of ischaemia-induced retinal neovascularisation area in the flatmounted retina compared with wild-type mice with OIR (Fig. 6a-d). Quantification of pre-retinal neovascular cells showed that Hif- $1 \alpha \mathrm{KO}$ mice with OIR developed significantly fewer pre-retinal neovascular cells (35\% of wild-type) than wild-type mice with OIR $(p<0.05$; Fig. 6e-g). These results suggest that HIF- $1 \alpha$ in Müller cells plays a vital role in ischaemia-induced retinal neovascularisation in OIR mice.

Disruption of the Hif-1 $\alpha$ gene in Müller cells attenuated retinal inflammation and vascular leakage induced by diabetes Experimental diabetes was induced in wild-type 

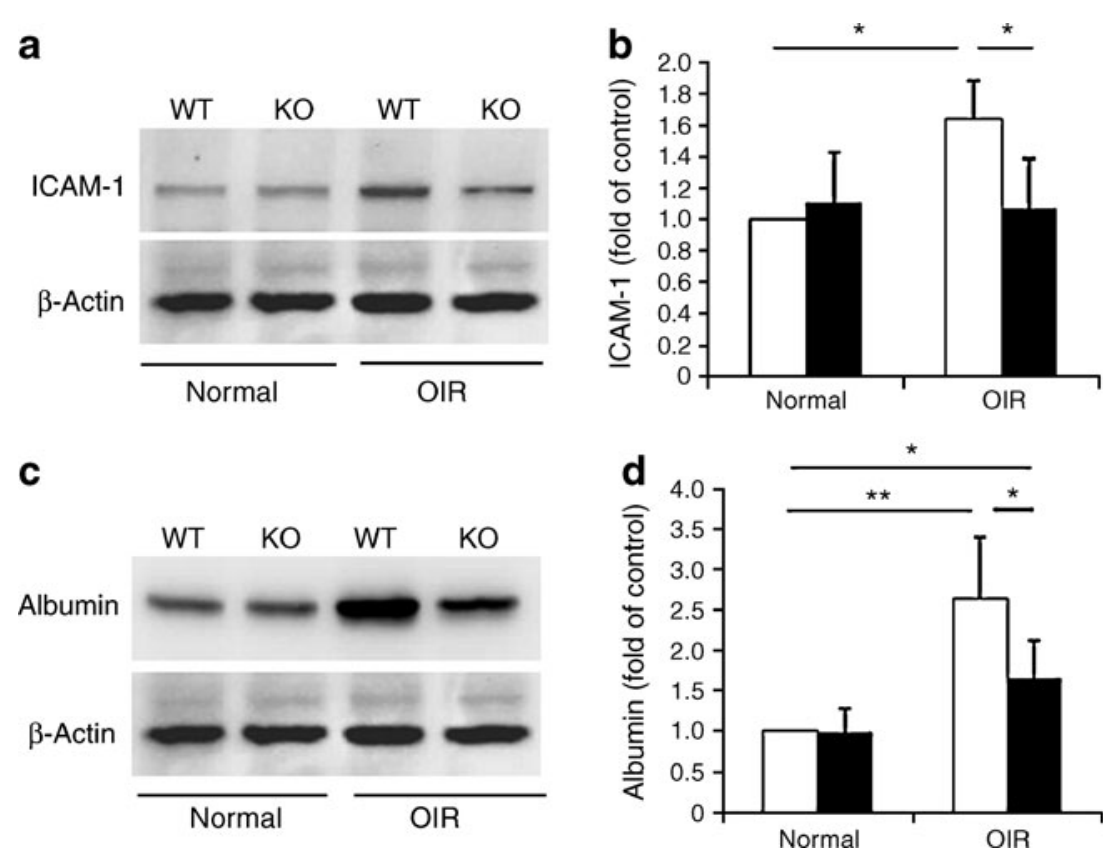

Fig. 5 Attenuated overabundance of ICAM-1 and decreased vascular leakage in retinas of Hif- $1 \alpha \mathrm{KO}$ mice with OIR. a The retina was dissected after thorough perfusion to remove blood in the vasculature. ICAM-1 and (c) albumin were measured by western blot analysis using $20 \mu \mathrm{g}$ retinal protein from each mouse at age P17 under normal

and Hif- $1 \alpha \mathrm{KO}$ mice by injections of streptozotocin and monitored by blood glucose measurements. No significant difference was detected in blood glucose levels or body weight between wild-type and Hif- $1 \alpha \mathrm{KO}$ mice with diabetes (ESM Table 1). Western blot analysis showed that diabetes induced a significant accumulation of HIF$1 \alpha$ in the retina of wild-type mice compared with nondiabetic wild-type mice (Fig. 7a). Disruption of the Hif-1 $\alpha$ gene in Müller cells resulted in significant decreases of HIF- $1 \alpha$ levels in the retina of Hif- $1 \alpha \mathrm{KO}$ mice under nondiabetic ( $70 \%$ of wild-type) and diabetic conditions (48\% of wild-type; Fig. 7a). Similarly, retinal VEGF and ICAM-1 were significantly upregulated by diabetes in wild-type mice, while their overproduction was attenuated in Hif- $1 \alpha \mathrm{KO}$ mice with diabetes (Fig. $7 b, c$ ). To determine retinal vascular leakage, albumin in the mouse retina was measured after thorough perfusion. As shown by western blot analysis, diabetes significantly increased retinal albumin in wildtype mice compared with non-diabetic wild-type mice. In contrast, the increase in diabetic Hif- $1 \alpha \mathrm{KO}$ mice was reduced (Fig. 7d).

Disruption of the Hif-1 $\alpha$ gene in Müller cells inhibited diabetes-induced leucostasis Leucostasis, or leucocyte adherence to the vasculature, is a major feature of retinal inflammation and early pathological changes in diabetic retinopathy. The amount of adherent leucocytes was conditions or with OIR. b ICAM-1 and (d) albumin levels were quantified by densitometry, revealing significantly lower ICAM-1 and albumin in Hif-1 $\alpha \mathrm{KO}$ (black bars) mice with OIR than in wild-type (WT; white bars) mice with OIR. Values $(\mathbf{b}, \mathbf{d})$ are mean \pm SEM; $n=6$; $* p<0.05$ and $* * p<0.01$

negligible in the retinal vasculature of non-diabetic wildtype and Hif- $1 \alpha \mathrm{KO}$ mice (data not shown), but increased dramatically in diabetic wild-type mice (Fig. 8). However, the level of adherent leucocytes in diabetic Hif-1 $\alpha \mathrm{KO}$ mice was only $34.9 \%$ of that in diabetic wild-type mice (Fig. 8d), suggesting that HIF-1 $\alpha$ in Müller cells plays an important role in mediating inflammation in diabetic retinopathy.

\section{Discussion}

Diabetic retinopathy is a common microvascular complication of diabetes $[28,29]$. Retinal neovascularisation, vascular leakage and retinal oedema are common pathogenic features in diabetic retinopathy and major causes of vision loss in patients with diabetes [15]. Diabetic retinopathy is a multi-factorial disorder. Clinical and experimental observations indicate that hypoxia or ischaemia are major driving forces of this pathological process [30]. HIF-1 $\alpha$ is the key regulator mediating the responses to hypoxia [30, 31]. Multiple proteins regulated by HIF$1 \alpha$ have been implicated in the pathogenesis of diabetic retinopathy, including VEGF, placental growth factor, stromal-derived factor 1, angiopoietin 2, platelet-derived growth factor B and erythropoietin [32]. To date, antiVEGF therapies have demonstrated their usefulness in 

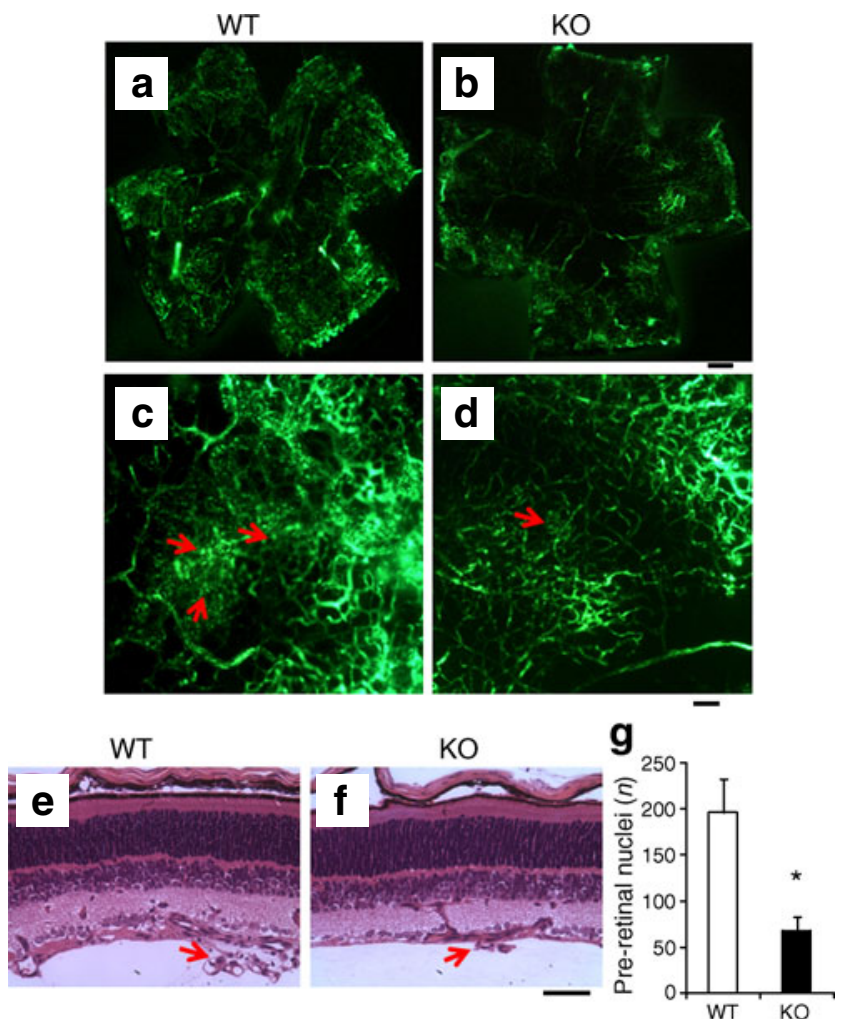

Fig. 6 Amelioration of ischaemia-induced retinal neovascularisation in Hif-1 $\alpha \mathrm{KO}$ mice with OIR. a-d Fluorescein angiography was performed with high molecular weight fluorescein-dextran in wildtype (WT) (a, c) and Hif-1 $\alpha \mathrm{KO}(\mathbf{b}, \mathbf{d})$ mice with OIR at age P17. Retinal angiography in whole mounted retina demonstrated smaller neovascularisation areas in retinas of $H i f-1 \alpha \mathrm{KO}$ mice with OIR than in those of WT mice with OIR. Arrows indicate neovascular tufts. Scale bars $100 \mu \mathrm{m}(\mathbf{a}, \mathbf{b}), 50 \mu \mathrm{m}(\mathbf{c}, \mathbf{d})$. e Haematoxylin- and eosinstained retinal sections of OIR-treated WT and (f) Hif- $1 \alpha \mathrm{KO}$ mice at age P17. Arrows indicate pre-retinal nuclei in the neovasculature. Scale bar $50 \mu \mathrm{m}$. g Quantification of neovascularisation was performed by counting pre-retinal nuclei in cross-sections of the eye. There were significantly fewer pre-retinal nuclei in Hif- $1 \alpha \mathrm{KO}$ than in WT mice with OIR. Values are mean \pm SEM; $n=4 ;{ }^{*} p<0.05$

treating ocular neovascularisation, but they only improve vision in less than $50 \%$ of treated patients, suggesting that pathogenic factors other than VEGF may also play an important role in non-responders. More and more evidence indicates that no single growth factor acts alone to cause retinal neovascularisation $[4,33]$. It is therefore crucial to identify an upstream regulator that regulates multiple pathogenic factors, not only to improve understanding of how diabetic retinopathy develops, but also to uncover new potential therapeutic targets. HIF-1 is a transcription factor regulating multiple angiogenic and inflammatory factors [4]. However, conclusive evidence of a pathogenic role of HIF-1 in diabetic retinopathy has not been obtained. The present study established a Müller cellspecific Hif-1 $\alpha \mathrm{KO}$ mouse model. In addition, it has shown for the first time that HIF-1 $\alpha$ in Müller cells is essential for ischaemia- and diabetes-induced retinal inflammation, vascular leakage and neovascularisation, suggesting that HIF- $1 \alpha$ is a promising candidate as an upstream drug target.

Although it is well known that HIF-1 mediates an orchestrated expression of angiogenic factors in multiple cell types within the ischaemic tissue in a temporally and spatially regulated manner [34], the major cellular location of HIF-1 accumulation in diabetic retina was virtually unknown. Retinal Müller cells are the major supporting glial cells contacting and ensheathing every type of neuronal cell body and process [15]. The role of retinal Müller cells in retinal neovascularisation was speculated on in 1995, in a study suggesting that retinal Müller cells are the major source of VEGF in patients with retinal neovascularisation [35]. In diabetic retinopathy, overproduction of angiogenic factor occurs mainly in the inner retinal cells such as Müller cells [36]. However, the role of growth factor overproduction driven by HIF-1 in Müller cells has not been established. Previous research has shown that disruption of Müller cell-derived VEGF in conditional Vegf (also known as Vegfa) KO mice with an inducible Cre/lox system significantly inhibited ischaemia-induced retinal neovascularisation, vascular leakage and breakdown of the blood-retina barrier, further suggesting that retinal Müller cell-derived VEGF is a major contributor to ischaemiainduced retinal vascular leakage and pre-retinal and intraretinal neovascularisation [15].

With the same inducible Cre/lox system [16] we generated Müller cell-specific Hif- $1 \alpha \mathrm{KO}$ mice and demonstrated that the loss of Müller cell-derived HIF- $1 \alpha$ did not significantly reduce expression of Vegf and other HIF- $1 \alpha$ target genes under normoxic conditions. To study the role of HIF-1 in Müller cells in response to stress conditions, Hif- $1 \alpha \mathrm{KO}$ mice were subjected to ischaemiainduced retinal neovascularisation and diabetes. These experiments showed that Hif- $1 \alpha \mathrm{KO}$ in Müller cells significantly attenuated ischaemia-induced retinal neovascularisation. Disruption of Hif-1 $\alpha$ in Müller cells also reduced ischaemia- or diabetes-induced retinal inflammation and vascular leakage. These observations suggest that HIF-1 produced in Müller cells plays a key role in retinal neovascularisation and vascular leakage in diabetic retinopathy. This finding not only provides new insights into the pathogenesis of diabetic retinopathy, but may also contribute to the development of cell-based therapeutics for diabetic retinopathy.

Chronic retinal inflammation has been shown to play a major pathogenic role in diabetic retinopathy [29]. Overabundance of ICAM-1 has been found in diabetic retinopathy and plays an important role in leucocyte adherence to the vasculature [37]. The present study shows that ICAM-1 overabundance in models of diabetic retinopathy is sup- 
Fig. 7 Comparison of diabetesinduced increases of retinal levels of HIF-1 $\alpha$, VEGF and ICAM-1, and of vascular leakage in wild-type (WT) and Hif-1 $\alpha$ KO mice. WT and Hif-1 $\alpha$ KO mice with 2 months of diabetes were perfused and retinas dissected. a Western blot analyses of HIF-1 $\alpha$, (b) VEGF, (c) ICAM-1 and (d) albumin were performed using the same amount of retinal protein from each mouse. HIF-1 $\alpha$, VEGF, ICAM-1 and albumin levels, as quantified by densitometry and normalised by $\beta$-actin levels, were significantly lower in diabetic Hif- $1 \alpha \mathrm{KO}$ (black bars) mice than in diabetic WT (white bars) mice. Values in bar graphs are mean $\pm \mathrm{SEM} ; n=5$; ${ }^{*} p<0.05$ and $* * p<0.01$ a
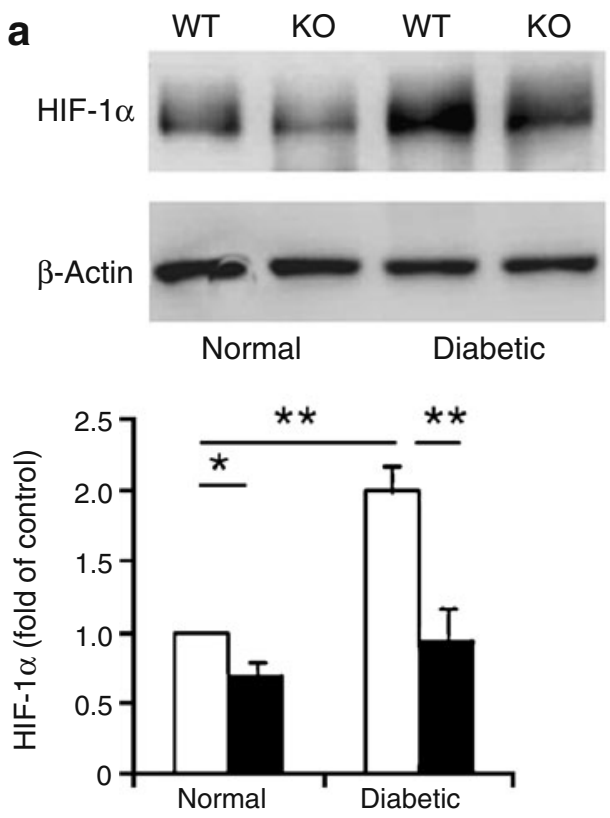

b

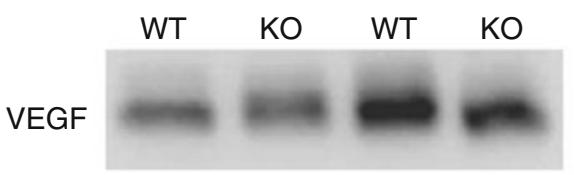

$\beta$-Actin

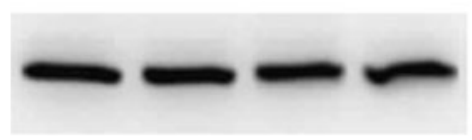

Normal

Diabetic

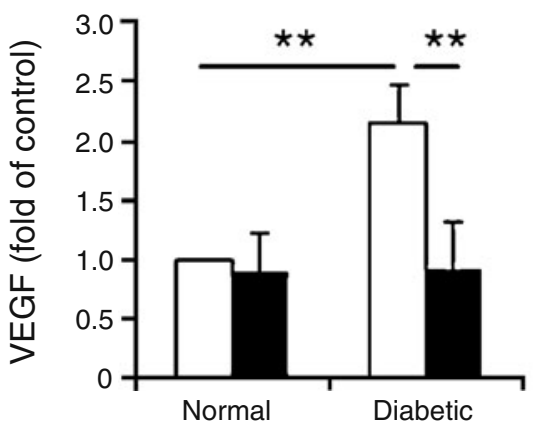

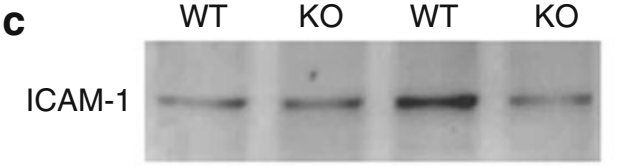

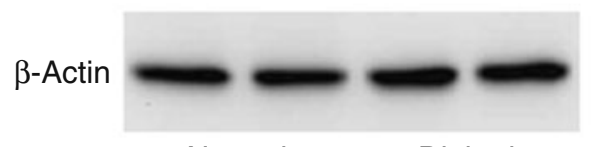

Normal

Diabetic

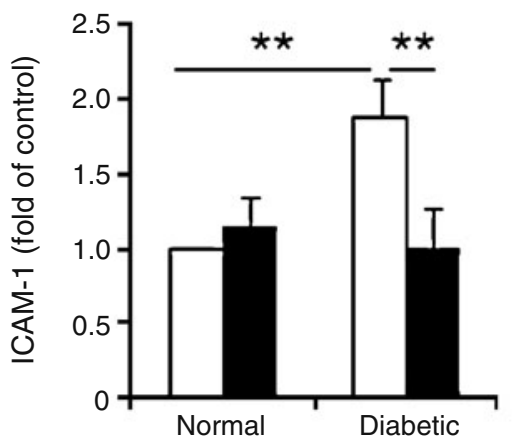

d

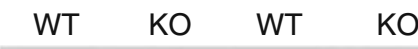

Albumin

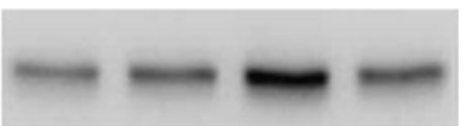

$\beta$-Actin

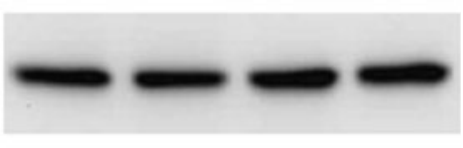

Normal

Diabetic

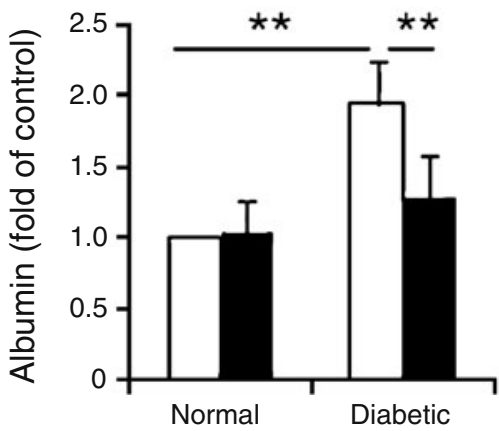

pressed in Hif-1 $\alpha \mathrm{KO}$ mice. This downregulation may contribute to the amelioration of leucostasis in the diabetic retina. Although the mechanism by which HIF-1 regulates ICAM-1 remains to be elucidated, these results suggest that HIF- $1 \alpha$ in Müller cells is also an important mediator of retinal inflammation in diabetic retinopathy.

OIR is a commonly used model of ischaemia-induced retinal neovascularisation $[2,38]$. Although it is not a diabetic model, its pathology, i.e. pre-retinal neovascularisation and pathogenesis, e.g. via overproduction of VEGF, is similar to that of proliferative diabetic retinopathy. It is therefore accepted as a model of proliferative diabetic retinopathy. With this OIR model, our wild-type mice showed accumulation of HIF- $1 \alpha$, and overproduction of VEGF and ICAM-1 in the retina, and also developed severe vascular leakage and preretinal neovascularisation. In contrast, in Müller cellspecific Hif- $1 \alpha \mathrm{KO}$ mice, increases of HIF-1 $\alpha$, VEGF, ICAM-1 and albumin in the retina were attenuated. Consistent with the decrease of multiple HIF- $1 \alpha-$ regulated angiogenic factors, numbers of retinal neovascular tufts and pre-retinal vascular cells, as well as retinal vascular leakage, were significantly reduced in Hif$1 \alpha \mathrm{KO}$ mice with OIR, suggesting that disruption of HIF- 

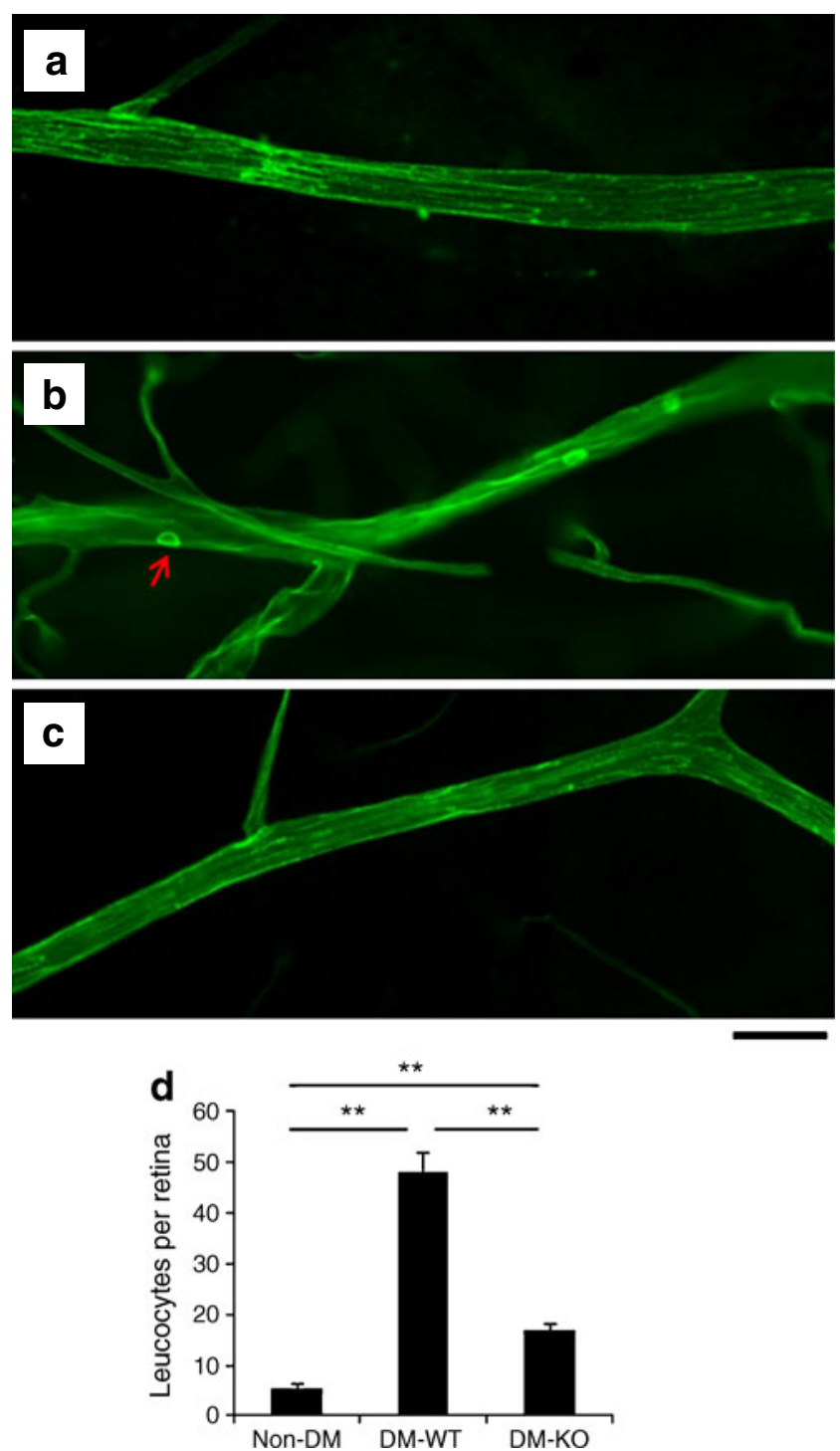

Fig. 8 Decreased leucostasis in a Hif- $1 \alpha$ KO mouse model of type 1 diabetes. a Non-diabetic mice, (b) diabetic wild-type (WT) mice and

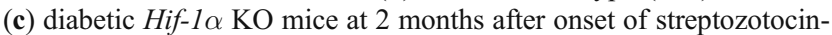
induced diabetes were used for leucostasis assay. Adherent leucocytes (arrow) were stained with FITC-conjugated concanavalin-A in the retinal vasculature after removal of circulating leucocytes by perfusion. The retinal vasculature and leucocytes were visualised in retinal flat mounts under fluorescence microscope. Scale bar $50 \mu \mathrm{m}$. d Adherent leucocytes in the retinal vasculature were counted and averaged, showing that diabetic (DM) Hif- $1 \alpha \mathrm{KO}$ mice had significantly fewer leucocytes than diabetic WT mice. Values are mean \pm SEM; $n=5, * * p<0.01$

$1 \alpha$ in Müller cells significantly blocks ischaemia-induced retinal neovascularisation and retinal vascular leakage.

It has been reported that HIF- $1 \alpha$ is upregulated in diabetic retinas, and that the accumulation and nuclear translocation of HIF- $1 \alpha$ result in overexpression of target genes such as Vegf [39-41]. There is some controversy regarding HIF-1 levels in the retina of animal models of diabetic retinopathy [42]. The disparities are likely to be due to different hyper- glycaemia levels, different duration of diabetes and different animal strains [43]. In our study, accumulation of HIF- $1 \alpha$ in diabetic retinas was also observed in a streptozotocininduced model of diabetes. Consistent with the increase of HIF- $1 \alpha$, VEGF and ICAM-1 in the diabetic retinas were significantly upregulated. As a result, retinal levels of albumin and levels of adherent leucocytes in diabetic retinas were elevated, indicating that inflammation occurred and developed in our model. Disruption of the Hif$1 \alpha$ gene in retinal Müller cells alleviated retinal inflammation and vascular leakage in diabetic Hif- $1 \alpha \mathrm{KO}$ mice, suggesting that Müller cell-derived HIF- $1 \alpha$ is an important contributor to diabetic retinopathy.

Since gene knockout using the cre/loxp system needs to be enhanced by doxycycline and cre-mediated recombination is not $100 \%$, conditional gene $\mathrm{KO}$ does not usually disrupt the gene in every targeted cell $[15,44]$. As a result, the Hif-1 $\alpha \mathrm{KO}$ efficiency must be confirmed before analysis of target gene expression. Our results in cultured Müller cells and in the retina both confirmed a significant reduction of HIF- $1 \alpha$ levels in Hif- $1 \alpha \mathrm{KO}$ mice. Moreover, recent research implies that HIF-1 $\alpha$, VEGF and erythropoietin all have neurotrophic activities [18, 45]. Our studies showed that no apparent difference in retinal VEGF levels was detectable between wild-type and Hif- $1 \alpha \mathrm{KO}$ mice, possibly because other transcription factors such as activator protein 1 , specificity protein 1 , Akt, nitric oxide and cytokines can compensate for HIF-1 function [46]. As a result, retinal morphology and function remained normal after knockout of Hif-1 $\alpha$ in Müller cells. This notion suggests strategies blocking HIF-1 in the treatment of diabetic retinopathy are likely to be safe.

Although we demonstrated that Müller cell-derived HIF- $1 \alpha$ was important for retinal inflammation and neovascularisation, our results do not exclude the possibility that other transcription factors are also involved in these processes. HIF- $1 \alpha$ may be regulated by multiple factors besides hypoxia, such as nitric oxide, reactive oxygen species, sirtuin 1 and nuclear factor kappa B [47]. Hyperglycaemia has been shown to regulate HIF- $1 \alpha$ protein stability by interfering with its proteasome degradation [48]. In addition, recent work has indicated that HIF-2 may be another important transcription factor that is upregulated in retinas with OIR and diabetic retinopathy [49]. Further research with this conditional Hif- $1 \alpha \mathrm{KO}$ mouse model will facilitate our understanding of the relationship between these signalling pathways.

In summary, the present study provides the first evidence showing that Müller cell-derived HIF-1 $\alpha$ is a pivotal contributor to diabetes- or ischaemia-induced retinal inflammation, vascular leakage and neovascularisation. Targeting HIF- $1 \alpha$ in Müller cells could be a new therapeutic strategy for the treatment of retinal vascular diseases. 
Acknowledgements The authors would like to thank I. Blader at University of Oklahoma Health Sciences Center for assistance with Hif-1a/floxp mice. This study was supported by National Institutes of Health grants EY018659, EY019309, EY20900 and P20RR024215, and by grants from the ADA, Foundation Fighting Blindness and Guangdong Natural Science Fund (grant GDNSF05001713).

Duality of interest The authors declare that there is no duality of interest associated with this manuscript.

\section{References}

1. Carmeliet P (2005) Angiogenesis in life, disease and medicine. Nature 438:932-936

2. Scott A, Fruttiger M (2010) Oxygen-induced retinopathy: a model for vascular pathology in the retina. Eye (Lond) 24:416-421

3. Ke Q, Costa M (2006) Hypoxia-inducible factor-1 (HIF-1). Mol Pharmacol 70:1469-1480

4. Rey S, Semenza GL (2010) Hypoxia-inducible factor-1-dependent mechanisms of vascularization and vascular remodelling. Cardiovasc Res 86:236-242

5. Loboda A, Jozkowicz A, Dulak J (2010) HIF-1 and HIF-2 transcription factors - similar but not identical. Mol Cells 29:435442

6. Wang GL, Jiang BH, Rue EA, Semenza GL (1995) Hypoxiainducible factor 1 is a basic-helix-loop-helix-PAS heterodimer regulated by cellular $\mathrm{O}_{2}$ tension. Proc Natl Acad Sci USA 92:5510-5514

7. Maxwell PH, Wiesener MS, Chang GW et al (1999) The tumour suppressor protein VHL targets hypoxia-inducible factors for oxygen-dependent proteolysis. Nature 399:271-275

8. Kamura T, Sato S, Iwai K, Czyzyk-Krzeska M, Conaway RC, Conaway JW (2000) Activation of HIF1alpha ubiquitination by a reconstituted von Hippel-Lindau (VHL) tumor suppressor complex. Proc Natl Acad Sci USA 97:10430-10435

9. Ivan M, Kondo K, Yang H et al (2001) HIFalpha targeted for VHL-mediated destruction by proline hydroxylation: implications for $\mathrm{O}_{2}$ sensing. Science 292:464-468

10. Jaakkola P, Mole DR, Tian YM et al (2001) Targeting of HIFalpha to the von Hippel-Lindau ubiquitylation complex by $\mathrm{O}_{2}-$ regulated prolyl hydroxylation. Science 292:468-472

11. Yu F, White SB, Zhao Q, Lee FS (2001) HIF-1alpha binding to VHL is regulated by stimulus-sensitive proline hydroxylation. Proc Natl Acad Sci USA 98:9630-9635

12. Epstein AC, Gleadle JM, McNeill LA et al (2001) C. elegans EGL-9 and mammalian homologs define a family of dioxygenases that regulate HIF by prolyl hydroxylation. Cell 107:43-54

13. Bruick RK, McKnight SL (2001) A conserved family of prolyl-4hydroxylases that modify HIF. Science 294:1337-1340

14. Semenza GL (2007) Hypoxia-inducible factor 1 (HIF-1) pathway. Sci STKE 2007: $\mathrm{cm} 8$

15. Bai Y, Ma JX, Guo J et al (2009) Muller cell-derived VEGF is a significant contributor to retinal neovascularization. J Pathol 219:446-454

16. Ueki Y, Ash JD, Zhu M, Zheng L, Le YZ (2009) Expression of Cre recombinase in retinal Muller cells. Vis Res 49:615-621

17. Thiersch M, Lange C, Joly S et al (2009) Retinal neuroprotection by hypoxic preconditioning is independent of hypoxia-inducible factor-1 alpha expression in photoreceptors. Eur J Neurosci 29:2291-2302

18. Ozaki H, Yu AY, Della N et al (1999) Hypoxia inducible factor1alpha is increased in ischemic retina: temporal and spatial correlation with VEGF expression. Invest Ophthalmol Vis Sci 40:182-189
19. Ryan HE, Poloni M, McNulty W et al (2000) Hypoxia-inducible factor-1alpha is a positive factor in solid tumor growth. Cancer Res 60:4010-4015

20. Das AV, Mallya KB, Zhao X et al (2006) Neural stem cell properties of Muller glia in the mammalian retina: regulation by Notch and Wnt signaling. Dev Biol 299:283-302

21. Chen Y, Hu Y, Moiseyev G, Zhou KK, Chen D, Ma JX (2009) Photoreceptor degeneration and retinal inflammation induced by very low-density lipoprotein receptor deficiency. Microvasc Res 78:119-127

22. Martin PM, Roon P, van Ells TK, Ganapathy V, Smith SB (2004) Death of retinal neurons in streptozotocin-induced diabetic mice. Invest Ophthalmol Vis Sci 45:3330-3336

23. Park K, Chen Y, Hu Y et al (2009) Nanoparticle-mediated expression of an angiogenic inhibitor ameliorates ischemiainduced retinal neovascularization and diabetes-induced retinal vascular leakage. Diabetes 58:1902-1913

24. Chen Y, Moiseyev G, Takahashi Y, Ma JX (2006) RPE65 gene delivery restores isomerohydrolase activity and prevents early cone loss in Rpe $65^{-1-}$ mice. Invest Ophthalmol Vis Sci 47: $1177-1184$

25. Zhang D, Kaufman PL, Gao G, Saunders RA, Ma JX (2001) Intravitreal injection of plasminogen kringle 5, an endogenous angiogenic inhibitor, arrests retinal neovascularization in rats. Diabetologia 44:757-765

26. Browning J, Wylie CK, Gole G (1997) Quantification of oxygeninduced retinopathy in the mouse. Invest Ophthalmol Vis Sci 38:1168-1174

27. Smith LE, Wesolowski E, McLellan A et al (1994) Oxygeninduced retinopathy in the mouse. Invest Ophthalmol Vis Sci $35: 101-111$

28. Cheung N, Wong TY (2008) Diabetic retinopathy and systemic vascular complications. Prog Retin Eye Res 27:161-176

29. Cheung N, Mitchell P, Wong TY (2010) Diabetic retinopathy. Lancet 376:124-136

30. DeNiro M, Al-Halafi A, Al-Mohanna FH, Alsmadi O, AlMohanna FA (2010) Pleiotropic effects of YC-1 selectively inhibit pathological retinal neovascularization and promote physiological revascularization in a mouse model of oxygen-induced retinopathy. Mol Pharmacol 77:348-367

31. Adams JM, Difazio LT, Rolandelli RH et al (2009) HIF-1: a key mediator in hypoxia. Acta Physiol Hung 96:19-28

32. Aiello LP, Pierce EA, Foley ED et al (1995) Suppression of retinal neovascularization in vivo by inhibition of vascular endothelial growth factor (VEGF) using soluble VEGF-receptor chimeric proteins. Proc Natl Acad Sci USA 92:10457-10461

33. Brown DM, Kaiser PK, Michels M et al (2006) Ranibizumab vs verteporfin for neovascular age-related macular degeneration. N Engl J Med 355:1432-1444

34. Kelly BD, Hackett SF, Hirota K et al (2003) Cell type-specific regulation of angiogenic growth factor gene expression and induction of angiogenesis in nonischemic tissue by a constitutively active form of hypoxia-inducible factor 1. Circ Res 93:1074-1081

35. Pierce EA, Avery RL, Foley ED, Aiello LP, Smith LE (1995) Vascular endothelial growth factor/vascular permeability factor expression in a mouse model of retinal neovascularization. Proc Natl Acad Sci USA 92:905-909

36. Amin RH, Frank RN, Kennedy A, Eliott D, Puklin JE, Abrams GW (1997) Vascular endothelial growth factor is present in glial cells of the retina and optic nerve of human subjects with nonproliferative diabetic retinopathy. Invest Ophthalmol Vis Sci $38: 36-47$

37. Miyamoto K, Khosrof S, Bursell SE et al (1999) Prevention of leukostasis and vascular leakage in streptozotocin-induced diabetic retinopathy via intercellular adhesion molecule-1 inhibition. Proc Natl Acad Sci USA 96:10836-10841 
38. Connor KM, Krah NM, Dennison RJ et al (2009) Quantification of oxygen-induced retinopathy in the mouse: a model of vessel loss, vessel regrowth and pathological angiogenesis. Nat Protoc 4:1565-1573

39. Chavez JC, Almhanna K, Berti-Mattera LN (2005) Transient expression of hypoxia-inducible factor-1 alpha and target genes in peripheral nerves from diabetic rats. Neurosci Lett 374:179-182

40. Kondo T, Kahn CR (2004) Altered insulin signaling in retinal tissue in diabetic states. J Biol Chem 279:37997-38006

41. Wang J, Xu X, Elliott MH, Zhu M, Le YZ (2010) Muller cellderived VEGF is essential for diabetes-induced retinal inflammation and vascular leakage. Diabetes 59:2297-2305

42. Wright WS, McElhatten RM, Messina JE, Harris NR (2010) Hypoxia and the expression of HIF-1alpha and HIF-2alpha in the retina of streptozotocin-injected mice and rats. Exp Eye Res 90:405-412

43. Zhang SX, Ma JX, Sima J et al (2005) Genetic difference in susceptibility to the blood-retina barrier breakdown in diabetes and oxygen-induced retinopathy. Am J Pathol 166:313-321
44. Le Y-Z (2011) Conditional gene targeting: dissecting the cellular mechanisms of retinal degenerations. J Ophthalmol 2011:806783

45. Nishijima K, Ng YS, Zhong L et al (2007) Vascular endothelial growth factor-A is a survival factor for retinal neurons and a critical neuroprotectant during the adaptive response to ischemic injury. Am J Pathol 171:53-67

46. Josko J, Mazurek M (2004) Transcription factors having impact on vascular endothelial growth factor (VEGF) gene expression in angiogenesis. Med Sci Monit 10:RA89-RA98

47. Majmundar AJ, Wong WJ, Simon MC (2010) Hypoxia-inducible factors and the response to hypoxic stress. Mol Cell 40:294-309

48. Catrina SB, Okamoto K, Pereira T, Brismar K, Poellinger L (2004) Hyperglycemia regulates hypoxia-inducible factor-1alpha protein stability and function. Diabetes 53:3226-3232

49. Mowat FM, Luhmann UF, Smith AJ et al (2010) HIF-1alpha and HIF-2alpha are differentially activated in distinct cell populations in retinal ischaemia. PLoS ONE 5:e11103 